\title{
Potentials of Carbon Stored in Plant Biomass at Little Farmers Grassland Cisarua, West Bandung Regency
}

\author{
Annas Dwitri Malik ${ }^{1,2}$, Komang Yoga Zso Zsa Dewa ${ }^{3}$, Parikesit ${ }^{2,3}$, Susanti Withaningsih ${ }^{2,3}$, \\ Ratna Wingit ${ }^{4}$ \\ ${ }^{1}$ Graduate Program of Sustainability Science, Universitas Padjadjaran, Indonesia \\ ${ }^{2}$ Center for Environment and Sustainability Science Universitas Padjadjaran, Indonesia \\ ${ }^{3}$ Department of Biology, Faculty of Mathematics and Natural Sciences, Universitas Padjadjaran, Indonesia \\ ${ }^{4}$ PT Bio Farma (Persero), Bandung, Indonesia \\ *Email: annas.dm27@gmail.com
}

Submitted: 21 January 2020. Revised: 11 February 2020. Accepted: 20 March 2020

\begin{abstract}
Alternatives of vegetations to store carbon need to be encouraged considering that forests are threatened by widespread destructions. One such vegetation is grasslands which have the potential for carbon storage and to reduce $\mathrm{CO}_{2}$ concentration in the atmosphere. At present, many enterprises have designed grasslands for animal feed. Grassland at Little Farmers, Cisarua, West Bandung was established for many purposes, i.e. recreation, education, and animal feed. The purpose of this research was to study the potential of carbon stock in grassland vegetation at this location. Based on RaCSA method, the tree biomass was determined by nondestructive collection of density and basal area of trees, then calculated by an allometric equation. The ground cover biomass was determined by destructive collection of grass and roots. Total measured biomass was multiplied by $46 \%$ to obtain carbon storage. Based on the results, the potential of carbon stock in Little Farmers grassland is $6,506.23 \mathrm{~kg} / \mathrm{m}^{2}$ with the potential for carbon storage below the ground $\left(0.129 \mathrm{~kg} / \mathrm{m}^{2}\right)$ was slightly higher than the carbon stored above the ground $\left(0.101 \mathrm{~kg} / \mathrm{m}^{2}\right)$. Carbon stored in ground cover had been proven to be lower than woody plants $(6,506$ $\mathrm{kg} / \mathrm{m}^{2}$ ). This study has pioneered in finding the carbon stocks potential of a man-made grassland, so it provides basis of an alternative land use that can be encouraged for carbon sequestration. For many enterprises, this study will aid in the conduct and management planning of grasslands with regards to ecosystem services preservation, such as carbon sequestration.
\end{abstract}

Key words: biomass, carbon, grassland, potential, stored, trees, understorey

How to Cite: Malik, A. D., Dewa, K. Y. Z. Z., Parikesit, P., Withaningsih, S., \& Wingit, R. (2020). Potentials of Carbon Stored in Plant Biomass at Little Farmers Grassland Cisarua, West Bandung Regency. Biosaintifika: Journal of Biology \& Biology Education, 12 (1), 111 118

DOI: http://dx.doi.org/10.15294/biosaintifika.v12i1.23111

\section{INTRODUCTION}

Plants have the ability to absorb $\mathrm{CO}_{2}$ from the atmosphere through the process of photosynthesis (Acharya et al., 2012). $\mathrm{CO}_{2}$ and $\mathrm{H}_{2} \mathrm{O}$ are converted to $\mathrm{O}_{2}$, and food reserves in the form of carbohydrates that are needed for plant's metabolic processes. These food reserves are stored in plants in a certain amount so that they can be expressed as biomass. Given that $\mathrm{CO}_{2}$ is the highest contributor to greenhouse gases (IPCC, 2006), the role of plants in absorbing carbon (carbon sequestration) is needed to reduce carbon emissions in the atmosphere.

At present, forests are the areas with the highest carbon storage in terrestrial ecosystems because in primary and old secondary forests there are mature trees. Carbon, which is the result of the conversion of $\mathrm{CO}_{2}$ in the atmosphere, will be partially stored in tree biomass. Biomass is consisted of organic materials both living and dead in aboveground and belowground
(Agostini et al., 2014). Carbon and biomass can be corellated to basal area of trees, hence a direct measurement of bole diameter of trees and application of allometric equation is adequate to measure the carbon stocks (Balderas Torres \& Lovett, 2013). The more basal area and diameter indicated the more biomass (Solomon et al., 2017) resulted in the more carbon storage (Atsbha et al., 2019).

However, forest destruction, climate change, and global warming cause a decrease in forest area, which means that they can reduce the forests' potential which is expected to store carbon at least 10 times greater than other types of vegetation. (Masripatin et al., 2010). A similar situation also happens in Indonesia. At the moment, carbon stored in primary highland forests in Indonesia is 103.16 tons/ ha. With the continued forest destruction, in 2015 to 2016 the deforestation was 0.63 million hectares and in 2017, the extent of deforestation stood at 0.48 million hectares with the most significant deforestation occurred in secondary forests both in and 
outside of the Forest Area (Ministry of Environment and Forestry Republic of Indonesia, 2018).

With this widespread forest destruction, other types of vegetation to store carbon need to be encouraged. One such vegetation is grasslands which have the potential for carbon storage to reduce $\mathrm{CO}_{2}$ 's concentration in the atmosphere (Acharya et al., 2012). About 3.5 billion hectares of land cover in the world are grasslands, representing 26 percent of all land in the world and 70 percent of all agricultural land in the world, and containing about 20 percent of belowground carbon of all the landmasses in the world (Conant, 2010). Tropical grasslands cover $15 \%$ of the earth's land surface and are complex landscapes where grasses, herbs, shrubs and trees co-exist in dynamic equilibrium (Schmidt et al., 2010). $\mathrm{CO}_{2}$ in the atmosphere is assimilated by green plants through photosynthesis, metabolism processes, and sequestration of some of that carbon in form of biomass and soil organic carbon which in turn can contribute to provide the ability of environmental and economic benefits in the grasslands where they exist (Follett \& Reed, 2010). Unlike carbon stored in forests, grasslands are dominated by herbaceous vegetation, so that aboveground vegetation of grasslands are contributed to a small proportion of the total ecosystem carbon pools (Ontl \& Janowiak, 2017). Even though the estimated rates of carbon sequestration per unit area in grasslands are lower than in agricultural land, sequestration potential of grasslands is comparable to that of croplands because of its large portion of coverage in the terrestrial ecosystems. (Conant, 2010).

The terrestrial soil has the potential twice as much carbon storage potential as the atmosphere, and photosynthesis plays an important role in assimilation of carbon in the plant's structures (Kell, 2012), especially roots (Carol Adair et al., 2009) which in turn produce most of soil carbon. This may indicate that loss of aboveground foliage caused by moderate grazing could be replaced by the rapid nutrition acquiring that was done by root growth (Carol Adair et al., 2009). The plant production could be affected by different grazing strategies which in turn may also regulate the formation of carbon soil. (W. Chen et al., 2015). An uncontrolled grazing management can lead to change in aboveground production and might affect little to the soil carbon change, because a heavy consumption and respiration of cattles would be accompanied by microbes respiration during degradation and the formation of soil carbon would not be available anyway (Pinero \& Paruelo, 2010). This type of continuous heavy grazing would be detrimental to the growth of the herbaceous plants which in turn may lead to the depletion of aboveground and soil carbon stocks (Atsbha et al., 2019). Because of these issues, we could find that a heavy grazing mechanism has many negative impacts to the potential of carbon stocks and aboveground vegetation has a great contribution to the carbon sequestration potentials. Based on research of (Atsbha et al., 2019), grazing lands with more aboveground vegetation have more contribution to carbon stocks potential of the carbon soil than communal heavy grazing lands which have less aboveground vegetation. Thereby, this grazing mechanism has advantages to avoid land degradation and desertification problems. (Pulido et al., 2018). Therefore, an effective grassland management can potentially return carbon released from the soil and become carbon sequences (Ghosh \& Mahanta, 2014)

A non-permanent grassland is cultivated for various purposes. It is generally used for animal feed (grazing area). At present, many enterprises have designed manmade grasslands for this purpose. Besides being used as a grazing area, man-made grasslands also have the ecosystem service values, one of which is the potential for carbon storage. However, there is still lack of information of carbon stored in grasslands since the potential of natural forests in carbon sequestration is still considered as the best. Therefore, there is a need to find the potentials of grasslands as an alternative vegetation for carbon storage, so that, its potential in carbon sequestration can be encouraged.

In addition to recreational and educational purposes, the site of the study, Little Farmers Cisarua, West Bandung Regency, was built for the maintenance of the grassland ecosystem. Furthermore, this area also had a role in the ecosystem services as a regulatory service. Ecosystems in an area of 7 ha can be categorized as a type of man-made grassland ecosystem that is dominated by stretches of Elephant Grass (Pennisetum purpureum) and interspersed by Eucalyptus (Eucalyptus spp.) as plants that play a role in storing carbon stocks in nature. Research on the calculation of carbon stored in plants at the Little Farmers area was needed to be carried out in order to determine the potential carbon stored in plants at the area. The purpose of this study was to find potentials of carbon stored in woody vegetation and ground cover biomass at Little Farmers grassland. By conducting this study, for researchers, we could provide a basis of an alternative land use for carbon sequestration by investigate its potential in carbon storage since the carbon storage data for managed grasslands are still inadequate. Moreover, for many enterprises, this study will aid in the implementation and management planning of grasslands with regards to 
ecosystem services preservation, such as carbon sequestration.

\section{METHODS}

\section{The Determination of Sample Plots}

Based on RaCSA (Rapid Carbon Stock Appraisal) method (Hairiah et al., 2011), the determination of sample plots was undertaken by assuming an area of land as a research plot. All individual trees were measured in one area of Little Farmers grassland. Then for the sampling of grass plants and roots, 30 sub-plots of 1 $\mathrm{m} \times 1 \mathrm{~m}$ were placed randomly. Little Farmers had an area of $73,005.13 \mathrm{~m}^{2}$ or around 7 hectares. The researchers conducted a particular delineation in the grassland area, establishing that the area of sampling was $47,706 \mathrm{~m}^{2}$ or around 4.7 hectares. The delineated area is shown in Figure 1.

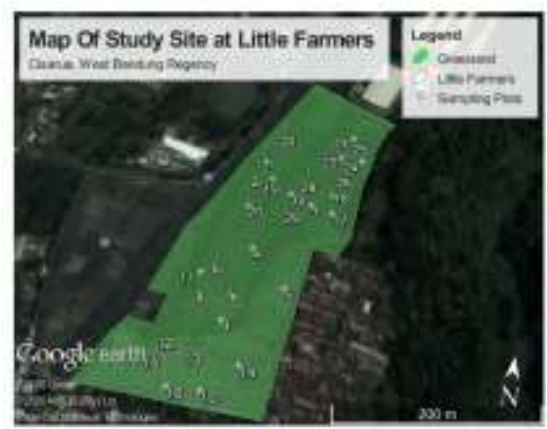

Figure 1. Sample Plots Distribution

\section{The Measurement of Tree Biomass}

The measurement of tree biomass was done nondestructively by recording the local name and scientific name of each tree. Then the diameter of the trunk (about 1.3 meters from the ground) and the height of each individual tree were noted on the observation sheet (Hairiah et al., 2011). The method to measure tree trunk diameters is shown in Figure 2.

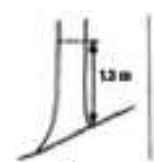

A

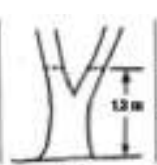

B

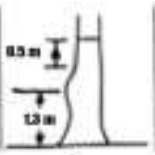

C

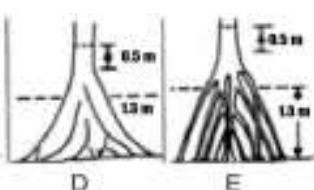

Figure 2. Schematics on how to determine the height measurements of tree trunks with irregular shapes (Weyerhauser \& Tennigkeit, 2000).

\section{The Measurement of Cover Ground Biomass (Grasses)}

The measurements of ground cover biomass were carried out destructively. The undergrowth taken as samples were all herbaceous plants and grasses. The sampling of the ground cover was carried out by taking the plant's above ground parts (Figure 3) and then weighed. The only part of the plant that was taken was the grass that was left or that was not pruned for animal feed needed in Little Farmers, which was about 15 - 30 $\mathrm{cm}$ from the ground. After that, around $100-300$ grams of plant samples were taken. If only a small amount of biomass was obtained $(<100 \mathrm{~g})$, then all of it was dried in an oven at $80^{\circ} \mathrm{C}$ for $2 \times 24$ hours until the sample did not contain water. The dry weight of the biomass sub-sample that was taken was then noted down in the observation sheet (Hairiah et al., 2011).

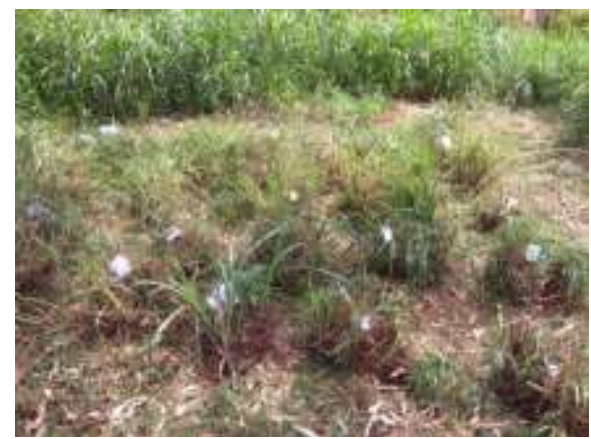

Figure 3. The sample of the ground cover which are the grasses' above ground parts

\section{The Measurement of Root Biomass}

The measurement of root biomass was done destructively. The roots of the grass samples were separated from the leaves and stems as shown in Figure 4. After that, around 100 - 300 grams of root samples were taken. If only a small amount of biomass was obtained $(<100 \mathrm{~g})$, then all of it was dried in an oven at $80^{\circ} \mathrm{C}$ for $2 \times 24$ hours until the sample did not contain water. The dry weight of the biomass sub-sample was then noted down in the observation sheet (Hairiah et al., 2011).

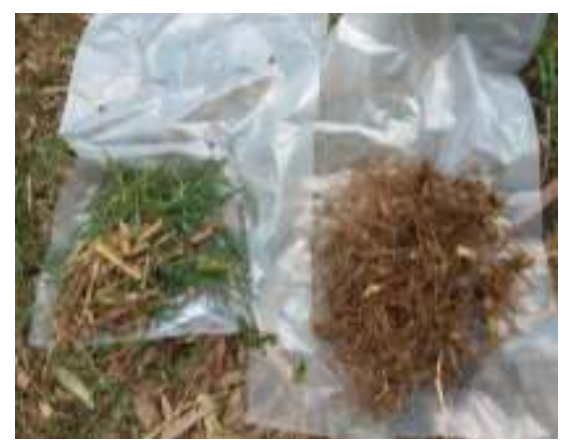

Figure 4. The result of leaves' and roots' separation 


\section{The Tree Biomass Analysis}

The collected parameters to obtain tree biomass consisted of stem diameter, tree height and density of wood. The density of wood for each tree species was obtained from the Global Wood Density Database compiled by Zanne et al. (2009). All parameters were analyzed using allometric equations developed by Chave et al. (2005).

\section{Biomass $=0.0509 \times \pi D^{2} H$}

with:

Biomass $=$ aboveground tree biomass $(\mathrm{kg} /$ individual of tree)

$\mathrm{D}=$ diameter of tree trunk $(\mathrm{cm})$

$\mathrm{H}=$ tree height $(\mathrm{m})$

$\pi=\operatorname{wood}$ density $(\mathrm{g} / \mathrm{cm})$

To obtain a measurement of carbon stored in trees, all tree biomass obtained from the allometric calculations was converted to units of tons. The size of carbon storage in all tree species in Little Farmers grassland area was obtained by adding up the carbon stored in all individual trees and then converting it into tons. Then the size of the biomass was divided by the total area of Little Farmers grasslands (4.77 hectares), so that the potential for carbon storage per hectare was obtained for all tree species.

\section{The Cover Ground and Root Biomass Analysis}

The collected parameters to measure ground cover biomass and roots were calculated and analyzed using the formula of total dry weight per sub plot area $\left(1 \mathrm{~m}^{2}\right)$ (Hairiah et al., 2011) :

$\operatorname{Tatal} D(g)=\frac{D \operatorname{sub}-\operatorname{sampl\theta }}{W \operatorname{sub}-\operatorname{sampl\theta }} \times \operatorname{Tatal} D(g)$

with:

$\mathrm{D}=$ Dry weight

$\mathrm{W}=$ Wet weight

\section{The Analysis of Carbon Storage per Unit Area}

To measure the carbon stored in Little Farmers grassland, the total biomass in the field was multiplied by the installed value of $46 \%$. This figure was taken because the carbon content was $46 \%$ of the biomass or necromass. The formula to calculate this is as follows (Hairiah \& Rahayu, 2007).

Carbon stored $($ tons $/$ ha $)=$ Biomass $($ tons $/$ ha $) \times 0.46$

\section{RESULTS AND DISCUSSION}

\section{The Average Carbon Stored in Tree Biomass}

The composition of tree species in the Little Farmers grassland consisted of 13 species and 244 individuals. The species that had the highest density or number of individuals was Eucalyptus (Eucalyptus spp.) with 145 individuals. Based on the measurement results, the potential for carbon storage in each tree species is shown in Table 1.

Furthermore, we serve a comparison between the carbon storage potential of five tree species with the highest density in Figure 5, they are Eucalyptus spp., Melaleuca leucadendra, Pometia pinnata, Ceiba pentandra, and Artocarpus heterophyllus.

Based on the graph in Figure 5, the highest carbon stock was in Eucalyptus (Eucalyptus spp.) with a carbon storage potential of 6.71 tons / ha. Eucalyptus belongs to a group of fast-growing trees (Amazonas et al., 2018), so that the growth of biomass over time takes place faster than Ceiba pentandra and Artocarpus heterophyllus. Furthermore, almost all individual trees of Eucalyptus had a large base area, indicated by the diameter of the trunk ranging from $20-60 \mathrm{~cm}$. The difference of carbon stored in Eucalyptus with other tree species was very significant, with the other four species having a carbon storage potential of less than 1 ton per hectare. This was heavily influenced by the number of individuals per hectare or the density of the Eucalyptus in the area. The obtained potential carbon storage of trees in the area was 6.51 tons / ha (Figure 6).

According to Yuliasmara et al. (2009), geometrically, tree biomass has a relationship that is parallel to the diameter, the density, and the height of the tree. Based on the result of the study, the biomass was found to be positively correlated to the carbon storage similar to a research by $\mathrm{He}$ et al. (2013).

One of many possible causes for such difference in the carbon storage pattern among species is the plant's physiological characteristics. As reported by Rindyastuti et al. (2018), there was a very strong correlation between the total of chlorophyll content and carbon storage which showed that the chlorophyll was an important factor in plant productivity. Plantations of fast-growing, exotic species accumulate more carbon than those of native species; plantations sequester more carbon in the plant biomass than naturally recovered vegetation, and carbon allocation patterns change with the tree species and stand age (Y. Chen et al., 2015). Therefore, Eucalyptus plantation may potentially facilitate ecological services, such as carbon sequestration. 
Annas Dwitri Malik et al. / Biosaintifika 12 (1) (2020): 111-118

Table 1. Potentials of carbon storage of each tree species

\begin{tabular}{lcccc}
\hline Species & $\begin{array}{c}\text { Biomass } \\
\text { (kg/area) }\end{array}$ & $\begin{array}{c}\text { Biomass } \\
\text { (tons/ area) }\end{array}$ & $\begin{array}{c}\text { Biomass } \\
\text { (tons/ha) }\end{array}$ & $\begin{array}{c}\text { Carbon } \\
\text { (tons/ha) }\end{array}$ \\
\hline Eucalyptus (Eucalyptus sp.) & 64018.594 & 64.019 & 13.421 & 6.174 \\
Weeping Paperbag (Melaleuca leucadendra) & 782.036 & 0.782 & 0.164 & 0.075 \\
Matoa (Pometia pinnata) & 663.996 & 0.664 & 0.139 & 0.064 \\
Venture Kapok (Ceiba pentandra) & 606.492 & 0.606 & 0.127 & 0.058 \\
Jackfruit (Artocarpus heterophyllus) & 198.173 & 0.198 & 0.042 & 0.019 \\
Guava (Psidium guajava) & 194.419 & 0.194 & 0.041 & 0.019 \\
Damar (Agathis dammara) & 220.757 & 0.221 & 0.046 & 0.021 \\
Pine (Pinus merkusii) & 266.027 & 0.266 & 0.056 & 0.026 \\
Acacia (Acacia mangium) & 189.553 & 0.190 & 0.040 & 0.018 \\
Candlenut (Aleurites mollucanus) & 223.375 & 0.223 & 0.047 & 0.022 \\
Jenitri (Elaeocarpus ganitrus) & 149.672 & 0.150 & 0.031 & 0.014 \\
Jamaican Cherry (Muntingia calabura) & 102.053 & 0.102 & 0.021 & 0.010 \\
Sea Mango (Cerbera manghas) & 11.935 & 0.012 & 0.003 & 0.001 \\
\hline
\end{tabular}

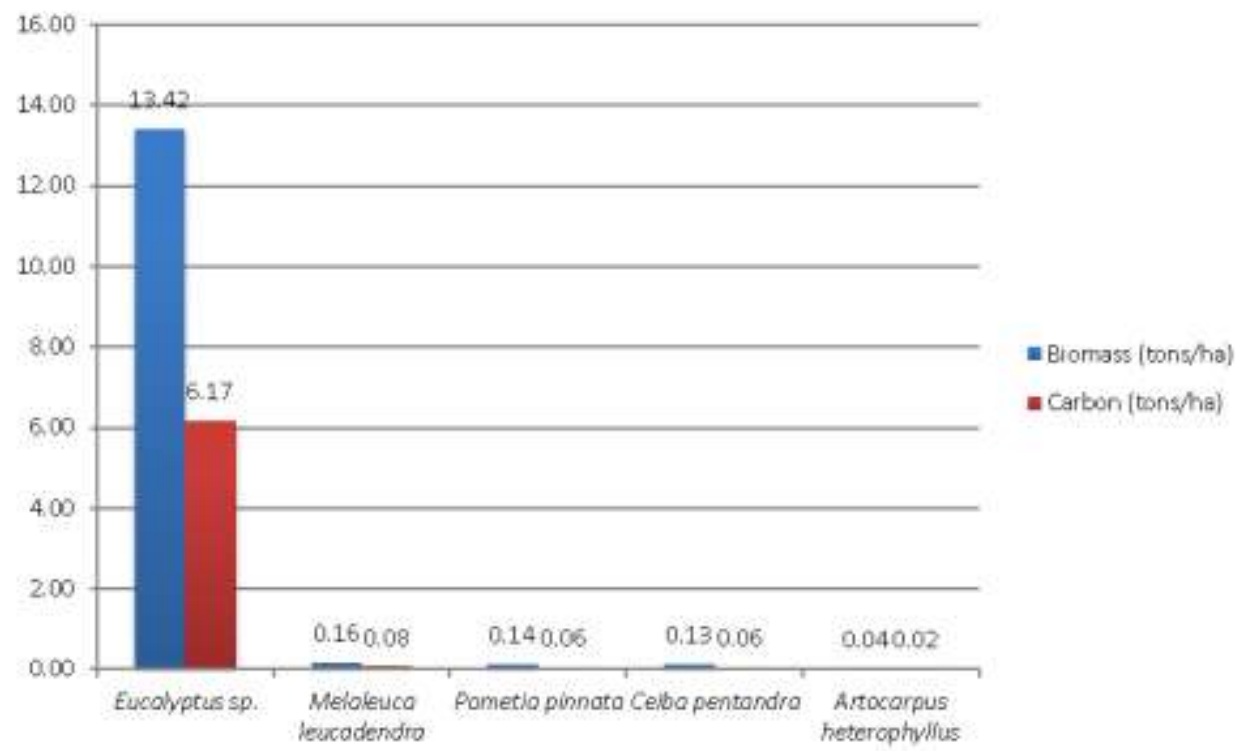

Figure 5. Comparison of carbon storage potential in five tree species with the highest density

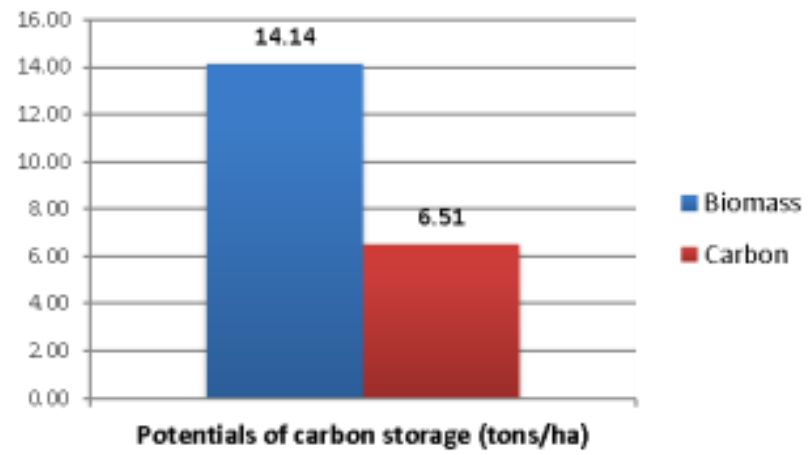

Figure 6. Potentials of Carbon Stored in Tree Biomass per Unit Area 


\section{The Average Biomass Stored in Ground Cover (Grasses)}

Grass age and management may affect the amount of carbon storage. The longer the grass is allowed to grow, the greater the potential for carbon storage. Usually, grasslands that used for grazing purpose can change aboveground biomass production in two ways, i.e., modify the vegetation composition and directly degrade the plant production with high utilization (W. Chen et al., 2015). The potential for grazed or mowed grassland carbon storage will be reduced when grass pruning is done because of the reduction in the biomass. The age of grass up to pruning varies depending on the level of animal feed needs.

Grass pruning at Little Farmers was done every 3 months or when it was almost flowering season and grass height was more than $3 \mathrm{~m}$. The yield of grass for every pruning reached almost 3 tons of biomass. Above ground biomass consists of leaves and stems. Carbon stored in aboveground biomass will continue to increase with the increase of the age of planting. However, along with the routine pruning which was done every 3 months, there was a certain amount of carbon that was "harvested". To reduce the inaccuracy in measuring the potential for carbon storage in aboveground biomass, only the parts of grasses which were not pruned were measured. The results of carbon measurements above and below ground level are shown in Table 2.

Based on Table 2, it can be seen that the potential for carbon storage of grasslands based on the results of ground cover biomass measurements above and below ground level was $0.229 \mathrm{~kg} / \mathrm{m}^{2}$. Carbon stored below the soil surface $\left(0.129 \mathrm{~kg} / \mathrm{m}_{2}\right)$ was slightly higher than the carbon stored above ground level $\left(0.101 \mathrm{~kg} / \mathrm{m}^{2}\right)$. According to (Acharya et al., 2012), carbon stored in subsurface biomass can be higher because root biomass will increase as grassland ages. Root biomass below the surface of the soil does not experience significant disturbance both in grazed grassland and mowed grassland unless ground breaking is carried out resulting in soil disturbance.

The average carbon stock of $0.229 \mathrm{~kg} / \mathrm{m}^{2}$ in the Little Farmers grassland was permanently stored. This aboveground biomass carbon has a relatively short age due to removal, cattle feeds, fire, and deteriotation with age (Ontl \& Janowiak, 2017). Given that the age of the grass planting cycle at Little Farmers was very short due to a short grass pruning period (every 3 months), carbon stock measurements were undertaken on uncut part of grasses. The grass biomass that was remain uncut will increase with age, but will alleviate when grassland's age has exceeded one year because the ability of photosynthesis of grass will weaken with the increasing age in consequence of reduced stomatal conductance (Acharya et al., 2012)

Climatically, rainfall affects the amount of aboveground biomass. Based on the results of research by Dinc et al. (2017) in Northwest Turkey, areas affected by higher rainfall will have higher amount of aboveground biomass (1.87 tons / ha and 1.57 tons / ha respectively). In addition, according to the research, the temperature also affects the amount of grassland biomass. Temperature determines the long or the short period of vegetation and this affects the amount of biomass above and below the soil surface.

\section{The Average Carbon Stored in Each Carbon Pool}

There were differences in the contribution of carbon stocks in each carbon pool (tree biomass, cover ground biomass, and root biomass) at the study site. The total amount of carbon stored in all carbon pool at the study site is shown in the graph in Figure 7.

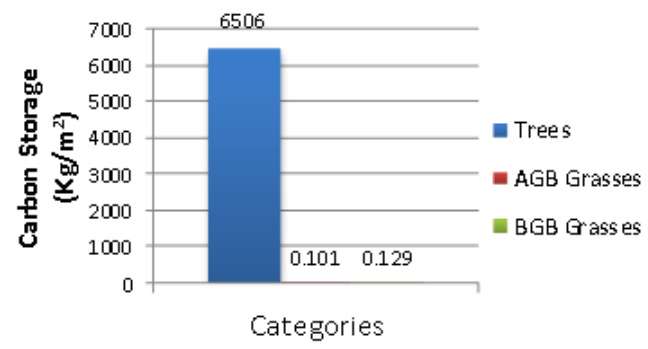

Figure 7. Average Carbon Stored on Each Carbon Pool

From Figure 7, it can be seen that the carbon stock in trees was the highest with $6,506 \mathrm{~kg} / \mathrm{m}^{2}$, significantly different from the carbon stock in both belowground and aboveground biomass of ground cover $(0.129 \mathrm{~kg}$ $/ \mathrm{m}^{2}$ and $0.101 \mathrm{~kg} / \mathrm{m}^{2}$ respectively). So that, potentials of carbon stock in Little Farmers grassland is 6,506.23 $\mathrm{kg} / \mathrm{m}^{2}$. Carbon stored in woody plants such as trees can certainly be higher than herbaceous plants or nonwoody plants because they had a higher wood density, height, and base area. This comparison was attributed to the fact that trees can produce more carbon carbon sequestration than ground cover because of its ability to accumulate more organic matter from the atmosphere and from the soil. (Cleveland et al., 2011). However, grass, herbs, and other understorey have a short to reach the reproductive stage, resulting in producing and growing new individuals abundantly (Murdjoko et al., 2016). Therefore, on a very large scale, grasslands can be considered in carbon accounting because grazings are now spreading all over the world. 
Annas Dwitri Malik et al. / Biosaintifika 12 (1) (2020): 111-118

Table 2. Measurement of Biomass and Carbon Stored in Ground Cover

\begin{tabular}{llllll}
\hline & Biomass $(\mathrm{g})$ & Biomass $(\mathrm{kg})$ & Carbon $(\mathrm{kg})$ & Carbon $\left(\mathrm{kg} / \mathrm{m}^{2}\right)$ & Total Carbon $\left(\mathrm{kg} / \mathrm{m}^{2}\right)$ \\
\hline Total K (AGB) & 6565.135 & 6.565 & 3.020 & 0.101 & \multirow{2}{*}{0.229} \\
\hline Total K (BGB) & 8391.517 & 8.392 & 3.860 & 0.129 & \\
\hline
\end{tabular}

Note : K = Dry Weight Biomass; AGB = Aboveground Biomass; BGB = Belowground Biomass

The research of carbon stocks potentials of manmade grasslands is hardly found in Indonesia, whereas many enterprises which established this type of vegetation as the result of their social responsibility are spreading in many locations. Encouraging this study might urgently needed in the recent condition of disturbed natural vegetation, i.e. forests. For researchers, this study showed a basis of an alternative land use that can be encouraged for carbon sequestration and for many enterprises this study will aid in the conduct and management planning of grasslands with regards to ecosystem services preservation, such as carbon sequestration.

\section{CONCLUSION}

Based on the results of the study, it can be concluded that the potential of carbon stock in Little Farmers grassland is $6,506.23 \mathrm{~kg} / \mathrm{m}^{2}$ with the potential for carbon storage below the surface of the ground $(0.129 \mathrm{~kg} /$ $\mathrm{m}^{2}$ ) was slightly higher than the carbon stored above the surface of the ground $\left(0.101 \mathrm{~kg} / \mathrm{m}^{2}\right)$. Carbon stocks in ground cover had been proven to be lower than woody plants $\left(6,506 \mathrm{~kg} / \mathrm{m}^{2}\right)$. Although carbon stocks in Little Farmers tend to be low due to the very short age of grass planting, the potential for carbon storage in the grassland can be increased through making some variations in the age of the grass planting cycle into a number of grass plots.

\section{ACKNOWLEDGEMENT}

The authors would like to thank to Academic Leadership Grant (ALG) 2020 Universitas Padjadjaran for supporting this study and PT Bio Farma for their trust to the Center for Environment and Sustainability Science (CESS), Universitas Padjadjaran for conducting the research at Little Farmers Agro Tourism in order to maintain their commitment to be oriented towards environmental programs which are "beyond compliance"

\section{REFERENCES}

Acharya, B. S., Rasmussen, J., \& Eriksen, J. (2012).

Grassland carbon sequestration and emissions fol- lowing cultivation in a mixed crop rotation. Agriculture, Ecosystems \& Environment, 153, 33-39.

Agostini, A., Giuntoli, J., \& Boulamanti, A. (2014). Carbon Accounting of Forest Bioenergy: Conclusions and Recommendations from a Critical Literature Review. Joint Research Centre of The European Comission.

Amazonas, N. T., Forrester, D. I., Oliveira, R. S., \& Brancalion, P. H. S. (2018). Combining Eucalyptus wood production with the recovery of native tree diversity in mixed plantings: Implications for water use and availability. Forest Ecology and Management, 418, 34-40.

Atsbha, T., Belayneh Desta, A., \& Zewdu, T. (2019). Carbon sequestration potential of natural vegetation under grazing influence in Southern Tigray, Ethiopia: Implication for climate change mitigation. Heliyon, 5(8), e02329.

Balderas Torres, A., \& Lovett, J. C. (2013). Using basal area to estimate aboveground carbon stocks in forests: La Primavera Biosphere's Reserve, Mexico. Forestry: An International Journal of Forest Research, 86(2), 267-281.

Carol Adair, E., Reich, P. B., Hobbie, S. E., \& Knops, J. M. H. (2009). Interactive Effects of Time, CO2, $\mathrm{N}$, and Diversity on Total Belowground Carbon Allocation and Ecosystem Carbon Storage in a Grassland Community. Ecosystems, 12(6), 1037-1052.

Chave, J., Andalo, C., Brown, S., Cairns, M. A., Chambers, J. Q., Eamus, D., Fölster, H., Fromard, F., Higuchi, N., Kira, T., Lescure, J.-P., Nelson, B. W., Ogawa, H., Puig, H., Riéra, B., \& Yamakura, T. (2005). Tree allometry and improved estimation of carbon stocks and balance in tropical forests. Oecologia, 145(1), 87-99.

Chen, W., Huang, D., Liu, N., Zhang, Y., Badgery, W. B., Wang, X., \& Shen, Y. (2015). Improved grazing management may increase soil carbon sequestration in temperate steppe. Scientific Reports, 5(1), 1-13.

Chen, Y., Liu, Z., Rao, X., Wang, X., Liang, C., Lin, Y., Zhou, L., Cai, X., \& Fu, S. (2015). Carbon Storage and Allocation Pattern in Plant Biomass among Different Forest Plantation Stands in Guangdong, China. Forests, 6(3), 794-808. 
Cleveland, C. C., Townsend, A. R., Taylor, P., Alvarez Clare, S., Bustamante, M. M. C., Chuyong, G., Dobrowski, S. Z., Grierson, P., Harms, K. E., Houlton, B. Z., Marklein, A., Parton, W., Porder, S., Reed, S. C., Sierra, C. A., Silver, W. L., Tanner, E. V. J., \& Wieder, W. R. (2011). Relationships among net primary productivity, nutrients and climate in tropical rain forest: A pan-tropical analysis. Ecology Letters, 14(9), 939-947.

Conant, R. T. (2010). Challenges and opportunities for carbon sequestration in grassland systems: A technical report on grassland management and climate change mitigation (Vol. 9). Food and Agriculture of The United Nations.

Dinc, M., Duman, A., Tufekcioglu, M., Kucuk, M., Harsit, C. A., \& Tufekclogu, A. (2017). Estimation of above and below ground biomass and carbon content in the grasslands of Bicakcilar and Kilickaya province in Artvin, Turkey. 96-101.

Follett, R. F., \& Reed, D. A. (2010). Soil Carbon Sequestration in Grazing Lands: Societal Benefits and Policy Implications. Rangeland Ecology \& Management / Journal of Range Management Archives, 63(1), 4-15.

Ghosh, P. K., \& Mahanta, S. K. (2014). Carbon Sequestration in Grassland Systems. Range Management and Agroforestry, 35(2), 173-181.

Hairiah, K., Andree, E., Rika Ratna Sari, \& Subekti Rahayu. (2011). Pengukuran Cadangan Karbon: Dari Tingkat Lahan ke Bentang Lahan: Petunjuk Praktis. Edisi kedua. World Agroforestry Centre.

Hairiah, K., \& Rahayu, S. (2007). Pengukuran "Karbon Tersimpan" Di Berbagai Macam Penggunaan Lahan. World Agroforestry Centre.

He, Y., Qin, L., Li, Z., Liang, X., Shao, M., \& Tan, L. (2013). Carbon storage capacity of monoculture and mixed-species plantations in subtropical China. Forest Ecology and Management, 295, 193-198.

IPCC. (2006). Guidelines for National Greenhouse Gas Inventories Volume 4 Agriculture,Forestry and Other Land Use. Intergovermental Panel on Climate Change.

Kell, D. B. (2012). Large-scale sequestration of atmospheric carbon via plant roots in natural and agricultural ecosystems: Why and how. Philosophical Transactions of the Royal Society B: Biological Sciences, 367(1595), 1589-1597.

Masripatin, N., G., K., Gustan P., Wayan S., Chairil A., Ari W., Dyah P., Arief S., Niken S., Mega L., Indartik, Wening W., Saptadi D., Ika H., Heriyanto N.M., Haris S., Ratih D., Dian A., Haruni K., ... Bayu S. (2010). Cadangan Karbon pada Berbagai
Tipe Hutan dan Jenis Tanaman di Indonesia. Pusat Penelitian dan Pengembangan Perubahan Iklim dan Kebijakan.

Ministry of Environment and Forestry Republic of Indonesia. (2018). The State of Indonesia's Forests 2018. Ministry of Environment and Forestry, Republic of Indonesia.

Murdjoko, A., Marsono, D., Sadono, R., \& Hadisusanto, S. (2016). Plant Species Composition and Their Conspecific Association in Natural Tropical Rainforest, South Papua. Biosaintifika: Journal of Biology \& Biology Education, 8(1), 33-46.

Ontl, T., \& Janowiak, M. (2017). Grassland Carbon Management. U.S. Department of Agriculture, Forest Services, Climate Change Resource Center. https://www.fs.usda.gov/ccrc/topics/grassland-andcarbon-management

Pinero, G., \& Paruelo, J. M. (2010). Pathways of Grazing Effects on Soil Organic Carbon and Nitrogen. Rangeland Ecology \& Management / Journal of Range Management Archives, 63(1), 109-119.

Pulido, M., Barrena-González, J., Badgery, W., Rodrigo-Comino, J., \& Cerdà, A. (2018). Sustainable grazing. Current Opinion in Environmental Science \& Health, 5, 42-46.

Rindyastuti, R., Rachmawati, D., Sancayaningsih, R. P., \& Yulistyarini, T. (2018). Ecophysiological and growth characters of ten woody plant species in determining their carbon sequestration. Biodiversitas Journal of Biological Diversity, 19(2), 610-619.

Schmidt, S., Lamble, R. E., Fensham, R. J., \& Siddique, I. (2010). Effect of woody vegetation clearing on nutrient and carbon relations of semi-arid dystrophic savanna. Plant and Soil, 331(1), 79-90.

Solomon, N., Birhane, E., Tadesse, T., Treydte, A. C., \& Meles, K. (2017). Carbon stocks and sequestration potential of dry forests under community management in Tigray, Ethiopia. Ecological Processes, $6(1), 20$.

Weyerhauser, H., \& Tennigkeit, T. (2000). Forest Inventory and Monitoring Manual. HBS-ICRAFCMU.

Yuliasmara, F., Wibawa, A., \& Prawoto, A. (2009). Karbon Tersimpan pada Berbagai Umur dan Sistem Pertanaman Kakao: Pendekatan Allometrik. 25(2), 86-100.

Zanne, A. E., Lopez-Gonzalez, G., Coomes, D. A., Ilic, J., Lewis, S. L., Miller, R. B., Swenson, N. G., Wiemann, M. C., \& Chave, J. (2009). Global Wood Density Database. Dryad. http://hdl.handle. net/10255/dryad.23 